
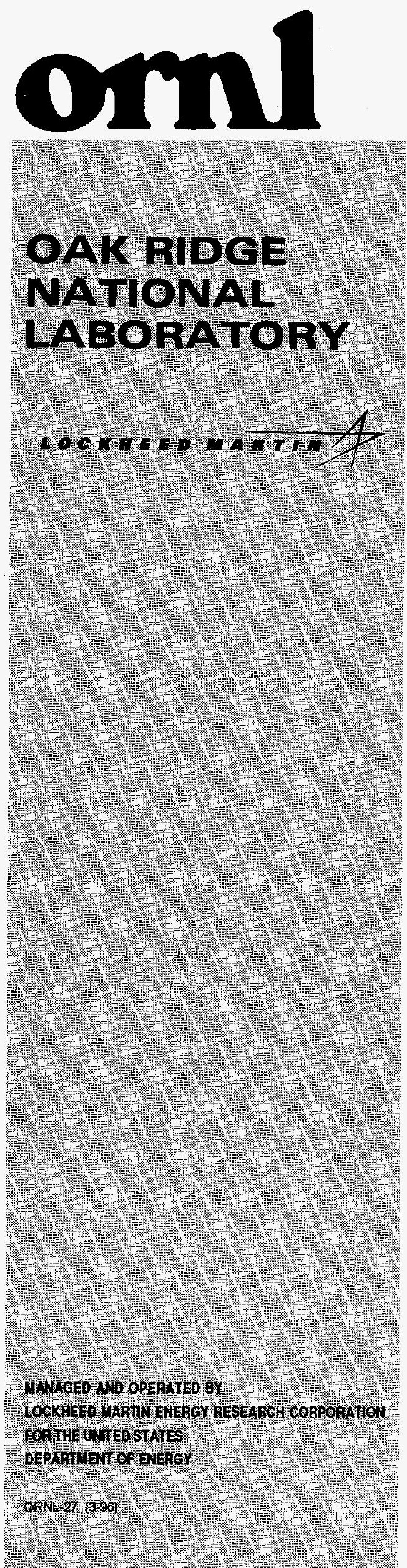

\author{
RECEIVED \\ MAR 181998 \\ OSTI
}

\section{Licensing Issues Associated With the Use of Mixed-Oxide Fuel in U.S. Commercial Nuclear Reactors}

D. L. Williams, Jr. 
This report has been reproduced directly from the best available copy.

Available to DOE and DOE contractors from the Office of Scientific and Technical Information, P.O. Box 62, Oak Ridge, TN 37831; prices available from (423) 576-8401.

Available to the public from the National Technical Information Service, U.S. Department of Commerce, 5285 Port Royal Rd., Springfield, VA 22161.

This report was prepared as an account of work sponsored by an agency of the United States Government. Neither the United States Government nor any agency thereof, nor any of their employees, makes any warranty, express or implied, or assumes any legal liability or responsibility for the accuracy, completeness, or usefulness of any information, apparatus, product, or process disclosed, or represents that its use would not infringe privately owned rights. Reference herein to any specific commercial product, process, or service by trade name, trademark, manufacturer, or otherwise, does not necessarily constitute or imply its endorsement, recommendation, or favoring by the United States Government or any agency thereof. The views and opinions of authors expressed herein do not necessarily state or reflect those of the United States Government or any agency thereof. 


\section{DISCLAIMER}

Portions of this document may be illegible electronic image products. Images are produced from the best available original document. 
ORNL/TM-13421

Dist. Category UC-523

\section{LICENSING ISSUES ASSOCIATED WITH THE USE OF MIXED-OXIDE FUEL IN U.S. COMMERCIAL NUCLEAR REACTORS}

D. L. Williams, Jr.

Date Published: April 1997

Prepared by

OAK RIDGE NATIONAL LABORATORY

Oak Ridge, Tennessee 37831 managed by

LOCKHEED MARTIN ENERGY RESEARCH CORP.

for the

U.S. DEPARTMENT OF ENERGY

under contract DE-AC05-96OR22464 


\section{Page Intentionally Blank}




\section{CONTENTS}

\section{Page}

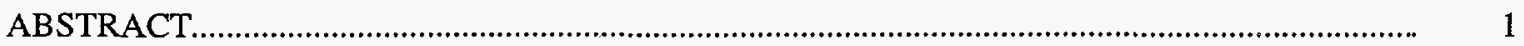

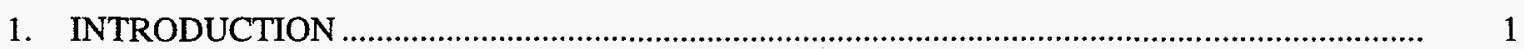

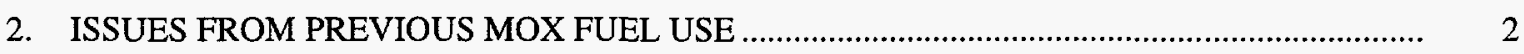

3. ISSUES FROM CURRENT REVIEWS OF PROPOSED MOX FUEL USE................................. 3

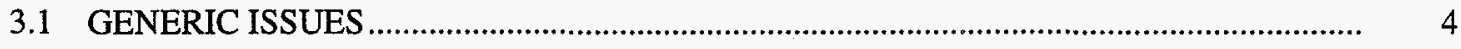

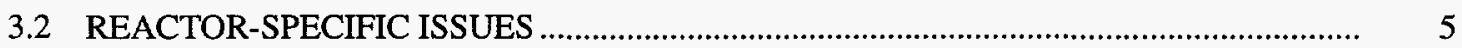

3.2.1 ABB-Combustion Engineering Reactors ........................................................... 5

3.2.2 General Electric Reactors ..................................................................................... 5

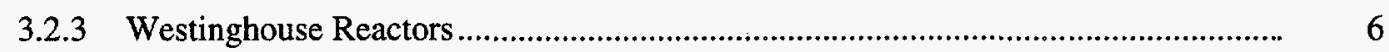

4. OTHER ISSUES OF POTENTIAL RELEVANCE.................................................................... 7

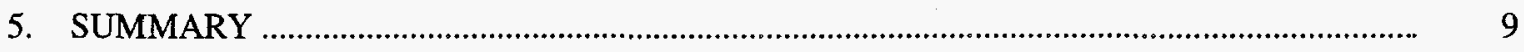

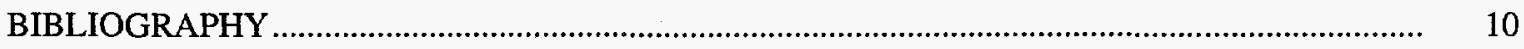


Page Intentionally Blank 


\title{
LICENSING ISSUES ASSOCIATED WITH THE USE OF MIXED-OXIDE FUEL IN U.S. COMMERCIAL NUCLEAR REACTORS
}

\author{
D. L. Williams, Jr.
}

\begin{abstract}
On January 14, 1997, the Department of Energy, as part of its Record of Decision on the storage and disposition of surplus nuclear weapons materials, committed to pursue the use of excess weapons-useable plutonium in the fabrication of mixed-oxide (MOX) fuel for consumption in existing commercial nuclear power plants. Domestic use of MOX fuel has been deferred since the late 1970s, principally due to nuclear proliferation concerns. This report documents a review of past and present literature (i.e., correspondence, reports, etc.) on the domestic use of MOX fuel and provides discussion on the technical and regulatory issues that must be addressed by DOE (and the utility/consortia selected by DOE to effect the MOX fuel consumption strategy) in obtaining approval from the Nuclear Regulatory Commission to use MOX fuel in one or a group of existing commercial nuclear power plants.
\end{abstract}

\section{INTRODUCTION}

On January 14, 1997, the Department of Energy (DOE) issued its Record of Decision (ROD) on the storage and disposition of surplus nuclear weapons materials. The ROD committed DOE to pursue a dualtrack program for this mission: (1) immobilizing excess weapons-useable plutonium in ceramic or glass forms for long-term storage and (2) using surplus plutonium to fabricate mixed-oxide (MOX) fuel for use in existing commercial nuclear power plants, thereby making the plutonium inaccessible (i.e., as spent nuclear fuel) for proliferation purposes. Consistent with the U.S. policy of nonproliferation of nuclear materials and technology, there will be no reprocessing and extraction of residual plutonium from the spent MOX fuel rods. Domestic use of MOX fuel has been deferred since the late 1970s, principally due to the nuclear proliferation concerns. However, with the successful development and implementation of the MOX fuel industry in Europe, the supportive position on MOX fuel use taken by a number of recognized international experts, and the need for a weapons-useable materials disposition program that provides a strong technical basis for the United States to negotiate multilateral or bilateral agreements related to nonproliferation and disarmament, it was decided to (1) proceed with the research and development activities in progress under DOE sponsorship that would support the production of MOX fuel elements using weapons-useable plutonium and (2) initiate the procurement of private-sector fuel fabrication and fuel irradiation services to accomplish the plutonium consumption track of the overall mission.

Given the nearly 20-year hiatus in the commercial use of MOX fuel in the United States, DOE recognized well before issuing its ROD that the domestic technology base supporting the safe and effective use of MOX fuel must be reestablished. This updated body of information is particularly important to DOE because the domestic use of MOX fuel in commercial nuclear power plants will require a licensing review and subsequent approval by the Nuclear Regulatory Commission (NRC). Consequently, several of the major suppliers of nuclear steam supply systems (NSSSs) in the United States (ABB-Combustion Engineering, General Electric, and Westinghouse) were tasked to review their hardware designs and system analyses and document the results of those reviews, including the identification of technically viable approaches that could be taken to license the consumption of MOX fuel in commercial nuclear power plants using their particular NSSS. The reports provided by the NSSS vendors and selected documentation from the 1970s on the commercial use of MOX fuel have been consulted for relevant hardware/analysis issues that could influence the licensing process. In addition, available information on the European MOX 
fuel industry was reviewed for administrative and operational issues that would likely be raised in NRC licensing reviews.

For the purpose of this topical report, an overarching assumption is made that certain institutional issues, such as (1) the achievement of international agreements (between the United States and Russia) confirming a bilateral, consistent approach to the plutonium consumption option and (2) the enactment of legislation authorizing NRC to conduct licensing reviews of and, subsequently, issue operating licenses to DOE nuclear facilities (i.e., the domestic MOX fuel fabrication facility described in the ROD), have been addressed in a manner that supports the completion of this track of the overall DOE materials disposition mission. Also, this report does not address either plutonium reprocessing issues or the technical and licensing issues associated with the design, construction, and operation of the domestic MOX fuel fabrication facility described in the ROD.

\section{ISSUES FROM PREVIOUS MOX FUEL USE}

As part of the evolution of the commercial nuclear power industry, work commenced in the 1950s [under the sponsorship of the U.S. Atomic Energy Commission (AEC), NRC's predecessor organization] to build the technology base for establishing the viability of using MOX fuel in commercial nuclear power plants. By the early 1970s, the AEC-sponsored work was being supplemented by commercial demonstration programs under private-sector sponsorship. Test assemblies containing MOX fuel were fabricated and inserted in the Big Rock Point, Dresden-1, Ginna, Quad Cities-1, and San Onofre-1 reactors. In addition to the individual licensing reviews conducted by AEC on the use of these test assemblies, a comprehensive review of the issues (e.g., fuel/reactor designs, licensing, environmental impacts, economics, reprocessing, etc.) associated with the expected wide-scale use of MOX fuel in commercial nuclear power plants was performed (Final Generic Environmental Statement on the Use of Recycle Plutonium in Mixed-Oxide Fuel in Light-Water Cooled Reactors, NUREG-0002, August 1976). Subsequently, as a result of the April 7, 1977, Executive Order on nonproliferation, essentially all activities associated with the use of MOX fuel in commercial nuclear power plants were terminated, redirected, or completed and archived.

From a review of selected documentation and reports from this period, the following issues were identified that may be germane to current efforts directed at receiving new regulatory authorization(s) to irradiate MOX fuel assemblies in commercial nuclear power plants.

1. Due to the scope of the review and its intended purpose, the Final Generic Environmental Statement on the Use of Recycle Plutonium in Mixed-Oxide Fuel in Light-Water Cooled Reactors (GESMO) can be considered the defining document on domestic MOX fuel use for the period leading up to the April 7, 1977, Executive Order on nonproliferation. Working from the assumption that MOX fuel would be used extensively in a U.S. commercial nuclear power industry that would grow into the hundreds of individual reactor units, GESMO addressed essentially all of the technical and regulatory issues that face the utility/consortia to be selected by DOE for providing MOX fuel irradiation services. Reactor-related issues cited in GESMO that appear to be relevant to the DOE materials disposition mission include the following:

- Any utility expecting to use MOX fuel will have to apply to NRC for an amendment to its operating license.

- Many of the nuclear properties of MOX fuel differ from uranium dioxide $\left(\mathrm{UO}_{2}\right)$ fuel nuclear properties. The most notable of the differences is the increased neutron cross section of the plutonium isotopes and the corresponding decrease in control rod worth. However, the altered nuclear properties can be largely accommodated by using various rod placement and enrichment schemes.

- The materials properties and performance of MOX fuel are, in many cases, indistinguishable from $\mathrm{UO}_{2}$ fuel, and in all cases, the differences are small.

- For postulated plant transients and accidents, there is no significant increase in public risk incurred from the use of MOX fuel. 
- Some fuel design issues requiring further review include fuel pellet cracking and the isotopic composition of the plutonium used in the MOX fuel.

- No changes are necessary in the methodology or calculational techniques used in required safety analyses.

- The effects of a loss of turbine load event (i.e., temperatures/pressures) are less severe in pressurized-water reactors (PWRs), but potentially more severe in boiling-water reactors (BWRs) because of reactivity increase due to rapid void collapse.

- A postulated PWR main steam line break results in rapid cooling of the core, leading to a potential return to criticality because of the more negative moderator coefficient. To address this concern, more control rods or a higher boron injection rate may be required; concurrently, more restrictive fuel management strategies may be needed to minimize such changes.

- The differences in the fuel types $\left(\mathrm{UO}_{2}\right.$ vs $\left.\mathrm{MOX}\right)$ are not significant in terms of radiological impact to the environment.

2. A separate NRC review in 1974 related to domestic MOX fuel use (Effects of Plutonium Utilization on the Performance of Light Water Reactors, WASH-1303, March 1974) cited several fuel management and operational issues to be addressed in licensing reviews, including (1) the importance of placing MOX fuel away from control rods to maintain rod worth, (2) giving fresh MOX assemblies a high-fuel exposure in their first cycle to avoid excessive power peaking in the second cycle, and (3) the apparent need to increase PWR and BWR boron injection system capability to handle event-related reactivity control demands.

3. Licensing reviews leading to previous AEC/NRC approvals of MOX fuel use emphasized the limited number of MOX fuel assemblies being irradiated. For example, supporting documentation for the Ginna application noted that only 4 of the 121 core fuel assemblies, or $3 \%$ of the total core, would contain MOX fuel. Also, the NRC's safety evaluation report on the Quad Cities-1 application noted that the addition of $40 \mathrm{MOX}$ rods to the $33,800 \mathrm{UO}_{2}$ rods resulted in a negligible perturbation on operating characteristics and that this activity was a small-scale irradiation for verifying design prior to full-scale use of MOX core designs in reloads.

It should be noted that many of the technical issues discussed in items 1 and 2 above have already been reconfirmed by the more recent studies performed in support of this program. However, all of these issues will almost certainly be reevaluated as part of the current initiative to obtain new authorization(s) from NRC for irradiating MOX fuel assemblies in commercial nuclear power plants. Also, the extent of NRC licensing actions during this period (discussed in item 3 above) appears to apply only in situations involving the use of a limited number (i.e., significantly less than the $30 \%$ MOX cores assumed for commencing this track of the materials disposition mission) of MOX fuel assemblies in each core.

\section{ISSUES FROM CURRENT REVIEWS OF PROPOSED MOX FUEL USE}

Given the nearly 20-year hiatus in the commercial use of MOX fuel in the United States, DOE recognized well before issuing its ROD that resources must be applied to reestablish the domestic technology base supporting the safe and effective use of MOX fuel. This updated body of information is particularly important to DOE because the domestic use of MOX fuel in commercial nuclear power plants will require a licensing review and subsequent approval by NRC. Consequently, several of the major suppliers of NSSS in the United States (ABB-Combustion Engineering, General Electric, and Westinghouse) were tasked to review their hardware designs and system analyses and, subsequently, document the results of those reviews, including the identification of technically viable approaches that could be taken to support licensing the consumption of MOX fuel in commercial nuclear power plants using their particular NSSS. As expected, several of the technical and regulatory issues identified by the NSSS vendors are generic to the MOX fuel irradiation licensing process, while others are specific to the vendor's NSSS design or the 
licensing strategy advocated by the vendor. In addition, both DOE and the NSSS vendors have made public presentations that included information on MOX fuel licensing strategies.

From a review of the available documentation and reports, a discussion on the generic and reactorspecific technical and licensing issues associated with MOX fuel use in commercial nuclear power plants is provided below.

\subsection{GENERIC ISSUES}

1. The use of MOX fuel affects a reactor's response to design basis accidents. The response changes from that experienced with uranium cores typically include a more negative moderator temperature coefficient, a generally more negative Doppler coefficient, increased control rod reactivity requirements, reduced individual control rod worth, reduced delayed neutron fraction, increased local power peaking factors, reduced prompt neutron lifetime, and reduced boron worth. The differences in plant response to normal operating transients and design basis accidents resulting from the employment of MOX fuel cores challenge, in some cases, safety margins that comprise, in part, NRC's technical basis for authorizing facility operations. As such, typical changes in domestic light-water reactors (LWRs) that may need to be implemented to reestablish those safety margins for gaining NRC acceptance of MOX fuel use include adding control rods to maintain excess shutdown margins, effecting equipment and administrative changes to accommodate higher soluble boron concentrations (or use of enriched boron), increasing reactor shutdown cooling and spent fuel pool cooling system capacities to address the higher decay heat loads from MOX fuel, employing measures to address the higher neutron flux and heating rates on the reactor vessel and internals, upgrading the plant radioactive waste systems to handle increased tritium activity, modifying the fuel storage facilities and handling equipment to accommodate the MOX fuel, and addressing new ALARA (as low as reasonably achievable) considerations through changes in plant procedures.

2. The utility/consortia selected by DOE to provide the MOX fuel irradiation services will want to limit the risks to continued operation of their reactor(s) from NRC licensing activities related to seeking approval for MOX fuel use. Consequently, similar to gaining approval on any new core design, the utility/consortia may choose to first seek generic NRC approval of the MOX core design. By employing this strategy, typical core performance, response, and management issues can be addressed without exposing the unit(s) to operational risks from external reviews during this period. Upon receipt of NRC approval of the MOX core design, the utility/consortia can submit the necessary license amendment documentation, which would include confirmatory information that the unit(s)' performance and response using MOX fuel is enveloped by the generic core analyses previously approved by NRC.

3. Typical plant and utility performance issues using MOX fuel to be addressed through the licensing process include fuel rod clad cracking; fuel rod bowing/peaking factors; results of core reload analyses; revised source term calculations; updated fission product inventories; revised safety analyses describing the performance of the reactor core [Final Safety Analysis Report (FSAR) Chap. 4], emergency core cooling system (FSAR Chaps. 5 and 6), fuel pool cooling systems (FSAR Chap. 9), and radioactive waste and radiation protection systems (FSAR Chaps. 11 and 12), including the plant's response to postulated accidents such as control rod ejection/drop, main steam line break, and loss of turbine load, and the resulting off-site consequences (FSAR Chap. 15); impacts from the possible use of enriched boron (i.e., water chemistry, corrosion, etc.); location of control rods to MOX fuel bundles; severe accident response (NUREG-1150) implications; impacts on resolution of generic issues (NUREG-0933), including issues related to fuel handling, training, assessment of risks, and operational stability; and implications of MOX fuel use to plant decontamination and decommissioning (D\&D) issues.

4. Documentation to be submitted to NRC by the utility/consortia selected by DOE to provide the MOX fuel irradiation services will, as a minimum, include an updated plant-specific environmental assessment (EA) or environmental impact statement (EIS); needed revisions to the plant's technical specifications (i.e., administrative matters, operational limits, setpoint changes, etc.); FSAR changes, including descriptions of physical changes, revised safety analyses, and confirmation of those safety analyses still 
valid; references to generic fuel design approvals received from NRC; and an updated physical security plan to address the receipt and storage of fresh MOX fuel, including the technical and procedural interfaces with the DOE fuel transportation system and state/local transportation authorities.

5. Security issues associated with the transportation and storage of MOX fuel may need to be addressed through rulemaking by NRC.

6. Postirradiation examination (PIE) of some of the initial MOX fuel rods will likely be required by NRC, even if data from foreign fuel vendors and DOE's current research and development activities indicate that MOX fuel rod performance is bounded by current industry experience and data for uranium fuel rods.

\subsection{REACTOR-SPECIFIC ISSUES}

\subsubsection{ABB-Combustion Engineering Reactors}

ABB-Combustion Engineering (ABB-CE) contends that the candidate plant for the MOX fuel irradiation mission (Palo Verde), which employs an ABB-CE NSSS (CE System $80^{\circledR}$ ), was originally designed for operation with a 100\% MOX core load (assuming the presence of integral burnable absorbers in the MOX fuel rods). As such, the plant is inherently rugged enough to handle a full MOX core with few physical, operational, or procedural changes. Also, even without the use of integral burnable absorbers in the MOX rods (DOE precondition for core designs using MOX fuel), Palo Verde can handle a higher MOX core load percentage than the other NSSS designs. Reference is made by ABB-CE to a 1994 study by the National Academy of Sciences citing Palo Verde (a three-unit plant) as having the capability to consume large quantities of excess weapons-useable plutonium. However, to minimize licensing risks, ABB-CE suggests that NRC approval of the utility documentation supporting a license application for MOX fuel use be obtained before fabrication of the MOX fuel begins.

Other relevant issues addressed in the ABB-CE report include the following:

1. $A B B-C E$ takes credit for an assumed DOE decision to build the MOX fuel fabrication facility at the Pantex site and cites the assumed decision as an advantage for its proposed strategy with respect to minimizing the number of transportation/security issues to be resolved through the NRC licensing process.

2. $A B B-C E$ notes that the boron concentration in the refueling water storage tank (RWST) and safety injection system (SIS) tanks would have to be increased for MOX fuel use; however, no physical plant modifications would be required (only technical specification changes). [ORNL comment: The impacts of an increased boron concentration on other plant features and safety systems will likely need to be addressed during the MOX fuel use licensing process.]

3. ABB-CE notes that in addition to increasing the boron concentration in the reactor coolant and safety systems, it may be desirable to replace the 13 existing part-length control rod assemblies with fulllength control rod assemblies. $\mathrm{ABB}-\mathrm{CE}$ also suggests that this replacement action take place before the licensing efforts for MOX fuel use commence. [ORNL comment: Certainly, if the updated analyses show that reduced safety margins are incurred in the absence of this modification, it can be assumed that NRC would likely require the installation and use of the full-length control rod assemblies before approving the use of MOX fuel at Palo Verde.]

\subsubsection{General Electric Reactors}

General Electric (GE) proposes that the utility/consortia selected by DOE for providing MOX fuel irradiation services focus their efforts on the early fabrication and insertion of one to four lead test assemblies/lead use assemblies (LTAs/LUAs). GE asserts that a clearly defined regulatory basis exists for licensing BWR use of MOX fuel and, as a result, only minor technical/administrative changes are needed 
to plant technical specifications. GE further contends that LUAs can be installed for initial use under Title 10 Code of Federal Regulations (CFR) Part 50.59 (i.e., the use of these lead assemblies does not constitute an unreviewed safety question). Using this approach would satisfy two basic issues in the MOX fuel use licensing process: (1) establishing the regulatory basis for use of MOX fuel while confirming that the design satisfies required criteria (per GE, this should be acceptable based on past domestic experience) and (2) defining/implementing new fuel physical security and accountability requirements. As a result, licensing risks are reduced by minimizing the differences between existing $\mathrm{UO}_{2}$ cores and partial MOX cores, thus facilitating early NRC approval. This, in turn, permits the plutonium consumption track of the overall DOE materials disposition mission to begin and, through operational success and further research and development, establish the technology base and licensing approach needed to obtain NRC approval for plant operation with a full $(100 \%)$ MOX core.

Other relevant issues addressed in the GE report include the following:

1. Even if analyses confirm that all generic fuel acceptance criteria are met by the new MOX fuel design, it is very likely that NRC will want to review the core reload designs and analyses prior to implementation.

2. Full MOX cores with integral burnable gadolinia poison are being developed commercially for international BWRs; consequently, concern about the need for an expensive, high-risk developmental program supporting the use of full MOX cores for the plutonium consumption track of the overall DOE materials disposition mission is not warranted.

3. Regarding the on-site handling of MOX fuel bundles, if significant americium is present in new fuel, additional ALARA provisions may be necessary.

4. Because of the higher plutonium content of MOX fuel, the fuel vendor will need to confirm that the nuclear methodologies employed for analyzing uranium fuel bundle and core designs are applicable and sufficiently accurate for this application. Also, the licensee will need to address performance issues related to the thermal-mechanical behavior of the MOX fuel internal to the fuel rod (i.e., the fuel pellets).

5. For the higher loading MOX cores, GE anticipates that some LUA physics testing may be required to demonstrate the applicability of existing codes and methods for confirming acceptable nuclear performance of the MOX fuel.

6. With regard to the use of LTAs/LUAs, fuel rod testing in test reactors may not suffice for domestic licensing purposes; that is, a multicycle LTA program may be needed, with or without PIE, before the MOX fuel will be licensed by NRC.

7. Although not required, plants may voluntarily modify their fuel handling procedures to include the use of hand-held alpha counters by their radiation safety personnel during movements associated with MOX fuel bundles.

8. The reevaluation of storage rack criticality analyses is essential for verifying the existence of adequate shutdown margin prior to MOX fuel bundle transfer from the reactor.

9. Joint NRC/licensee/contractor planning meetings should be held to determine the type, extent, and schedule of licensing activities for the use of MOX fuel designs. In addition, the utility/consortia must review all licensing commitments and procedures for impacts from the use of MOX fuel.

\subsubsection{Westinghouse Reactors}

Westinghouse proposes that the utility/consortia selected by DOE to provide both MOX fuel fabrication and irradiation services apply to NRC for a manufacturer's license under 10 CFR 52, Appendix M 
("Standardization of Design; Manufacture of Nuclear Power Reactors; Construction and Operation of Nuclear Power Reactors Manufactured Pursuant to Commission License") and, through this license application, address all technical and licensing issues associated with MOX fuel fabrication, qualification, transportation, performance, and environmental impacts generically. When the manufacturer's license has been issued by NRC, the utility/consortia tasked with MOX fuel irradiation would need only to submit a plant-specific license amendment request together with confirmatory information that the generic MOX fuel use analyses approved by NRC through the issuance of the manufacturer's license are bounding for their application. Any licensing issues raised at this point would pertain only to the individual plant and not to the MOX fuel.

Other relevant issues addressed in the Westinghouse report include the following:

1. With the partial MOX core designs requiring high boron concentrations at the lower operational modes (Modes 2-6), Westinghouse notes that it is likely the limits of current plant accommodations for the higher boron concentration would be reached. Also, pH levels could become a concern at the higher boron concentrations. As such, Westinghouse recommends that the use of both integral burnable absorbers and enriched boron in the coolant be strongly considered for both partial and full MOX cores. Also, for full MOX cores, higher worth control rods would be needed to increase the available excess shutdown margin; in addition, the higher worth control rods (located in the shutdown banks) are suggested for partial MOX cores to provide additional excess shutdown margin.

2. In citing the probable need for PIE of a few MOX fuel rods after initial irradiation, Westinghouse notes that qualified domestic laboratories for performing these examinations may not exist. [ORNL recommendation: The existence of domestic laboratories that are qualified to perform PIEs of irradiated MOX fuel rods should be confirmed during the MOX fuel fabrication/irradiation services procurement process.]

3. In describing MOX core designs, Westinghouse notes that integral fuel burnable absorbers (IFBAs) in LEU fuel assemblies burn faster than the wet annular burnable absorbers (WABAs) in the MOX fuel assemblies. This situation leads to large reactivity differences between LEU and MOX feeds, resulting in high-power peaking. The situation was subsequently resolved by putting some WABAs in LEU feeds (per Westinghouse, WABA use in LEU cores is not a common practice).

4. Plant changes, such as increasing safety injection flow, boron concentration, and/or boron enrichment, are probably needed to ensure long-term subcriticality in the event of an anticipated transient without scram (ATWS) event, assuming the presence of a full MOX core.

\section{OTHER ISSUES OF POTENTIAL RELEVANCE}

1. The Storage and Disposition of Weapons-Useable Fissile Materials Final Programmatic Environmental Impact Statement (DOE/EIS-0229, December 1996) discusses the impacts of MOX fuel use (assuming a $40 \%$ MOX core) on severe accident analyses done using probabilistic risk assessment (PRA) methods or other risk assessment approaches described in NUREG-1150. It indicates that the consequences in most severe accident scenarios could worsen by approximately 10-20\%. The programmatic environmental impact statement (PEIS) also notes that more detailed calculations are needed for licensing purposes and the National Environmental Policy Act (NEPA) reviews to consider up-to-date calculations of radionuclide inventories for different fuel compositions and irradiation histories and population exposure models for sensitivity changes. The expectation exists that the PEIS will address most of NRC's information needs for its licensing reviews. However, one NRC commissioner recently expressed some concern about the adequacy of DOE's work in this area. As such, whether the PEIS meets NRC's information needs to "tier down" for its environmental assessment work is yet to be determined. 
2. A recommendation has been made to convene a joint NRC/DOE task force to identify the policy and regulatory issues in this area. Such a task force could address issues related to (1) legislative language defining NRC's oversight role and its relationship with other regulatory agencies; (2) identification of DOE facilities, activities, and issues subject to NRC oversight; (3) schedules for transition to NRC oversight; (4) assessment of NRC financial/personnel resource needs for this work; and (5) assessment of options for funding the NRC oversight activities. [ORNL recommendation: The results of the DOE/NRC discussions, including any recommendations that may evolve from the proposed joint agency task force, should be made available in sufficient time to be considered by the different utilities/consortia that will be submitting proposals to DOE for the fuel fabrication and irradiation services.]

3. The utility/consortia selected by DOE to provide both MOX fuel fabrication and irradiation services will want assurances that NRC will not take the opportunity to "ratchet" them into new licensing commitments because of (1) existing (unstated) concerns of NRC with utility management or plant operations and (2) NRC's need to address some emerging or generic licensing issue. [ORNL recommendation: This matter should be reviewed with NRC during the MOX fuel fabrication/ irradiation services procurement process.]

4. NRC is currently expanding its role on the review of the financial qualifications of utilities. As such, this issue could be raised during NRC's review of license amendment requests related to MOX fuel use.

5. It is likely that NRC will question utility plans for addressing possible interruptions in MOX fuel supply due to shifts/changes in U.S./Russian policy, speed of program implementation, and/or postulated accidents.

6. In their technical reports, the NSSS vendors indicate that in most cases, plant design and safety margins are not affected by the use of MOX fuel. However, NRC will view these statements in light of specific operating histories of plant(s) selected for the mission. Judgement will likely be applied as to whether the advertised design and safety margins have been or are being preserved. This will likely be reflected in NRC's approach to the licensing review with the utility/consortia selected for the mission.

7. It is likely that in addition to reviewing licensee submittals on MOX fuel use, NRC will want to also review the DOE laboratory research and development reports that compose the updated technology base supporting domestic MOX fuel use. Any NRC concerns with the technical adequacy of those reports could affect the MOX fuel licensing process.

8. The issue of the presence of gallium in the excess plutonium and its possible corrosive effect on fuel cladding will likely require priority attention to ensure a resolution is achieved that meets NRC's information needs. However, because a significant amount of the excess plutonium does not contain any gallium, the possibility exists (and should be explored) of starting the MOX fuel fabrication/irradiation mission using only the excess plutonium without gallium. This action would be taken with the understanding that NRC will likely condition its authorization of MOX fuel use on the satisfactory resolution of the gallium issue prior to its introduction into the MOX fuel fabrication process.

9. The utility/consortia selected for the mission will need to re-review their responses to past NRC bulletins, information notices, circulars, and administrative letters; cited violations/deviations from NRC inspections; and generic NRC licensing actions, such as the TMI Action Plan (NUREG-0660/0737), to confirm any issues (i.e., plant licensing commitments) that could be influenced by MOX fuel use have been or will be addressed.

10. At the February 21, 1997, technical exchange between the Nuclear Energy Institute (NEI) and NRC on the use of MOX fuel in LWRs, a presentation was made by a representative from Electricité de France 
(EdF) on the impacts of MOX fuel use (currently limited to 30\% of the core) in the EdF 900-MW(e)

PWRs. Key technical issues covered in the presentation are described below.

- Impacts on the reactor from MOX fuel use include reactivity shutdown margin decrease, safety injection efficiency decrease, and low boron makeup system capacity (shutdown situations). To address these issues, the number of control rod clusters for each reactor using MOX fuel was increased from 53 to 57 , and the boron concentration in the RWST and boron makeup tank was increased to $2500 \mathrm{ppm}$ and $7500 \mathrm{ppm}$, respectively.

- For transport of fresh MOX fuel, a new container was designed. Because the new container was heavier, the fuel building handling crane had to be reinforced.

- Fresh MOX fuel receipt is administratively controlled to occur no more that two weeks before a scheduled unit shutdown. Dry storage of the fresh MOX fuel is not permitted. Also, new fuel building access restrictions are employed (maximum of eight operators in the building during MOX fuel handling).

- Fuel handling procedures were modified such that there is no movement of a MOX fuel assembly at more that $70 \mathrm{~cm}$ from the floor.

- For checking of fresh MOX fuel, specific controls were added before opening of the fuel container (temperature, gamma, and neutron measurements). A special cell was designed for examining fuel (optical system to reduce doses). Also, only those examinations of the fuel deemed necessary were conducted. In addition, EdF procedures were adapted to comply with EURATOM and French government regulations on fuel handling (up to closure of fuel in the reactor vessel) concerning information on, access to, and physical protection of the MOX fuel.

- Regarding the handling of spent MOX fuel assemblies, the minimum cooling period is 2.5 years (1 year for $\mathrm{UO}_{2}$ assemblies); this results in the need to shift assemblies to a separate storage center or provide more fuel pool storage through re-racking. Also, transport of the spent MOX fuel assemblies is handled by standard fuel shipping casks (four MOX assemblies surrounded by eight $\mathrm{UO}_{2}$ assemblies).

[ORNL recommendation: The issues covered in the EdF presentation may be relevant to the licensing of domestic MOX fuel use. As such, the utility/consortia selected by DOE to provide MOX fuel irradiation services should be prepared to address these same issues in their licensing interactions with NRC. Also, EdF's developmental activities supporting the use of an increased percentage of MOX fuel in the reactor core (through the employment of newer fuel rod designs and core management strategies) should be followed for issues that could influence domestic MOX fuel use licensing reviews.]

\section{SUMMARY}

DOE is proceeding with the necessary research and development and service procurement activities that would support the domestic production of MOX fuel elements using weapons-useable plutonium and the irradiation of the MOX fuel in one or a set of commercial nuclear power plants. Indication has been provided that the Department, in executing this mission, intends to pursue (through the utility/consortia selected to provide the services) obtaining NRC authorization for plant operation with a partial MOX core (approximately $30 \%$ ) and then, through experience and testing, increase the MOX core loading to $100 \%$. Assuming the successful resolution of the institutional issues briefly discussed in the "Introduction" of this report and considering both the previous domestic experience from the 1970s and the current experience of the European MOX fuel industry, the plutonium consumption strategy can be successfully implemented. However, a key element to the eventual success of this strategy will be the ability of the utility/consortia to resolve NRC licensing issues and concerns related to MOX fuel use without the reactor(s) designated for MOX fuel irradiation being exposed to undue operational risks from the MOX fuel use licensing process.

Each of the three NSSS vendors has proposed a different approach for working with NRC on MOX fuel licensing. $\mathrm{ABB}-\mathrm{CE}$, with a candidate plant that was originally designed for operation with a full MOX core (assuming integral burnable absorbers in the MOX fuel), recommends that NRC approval of the utility 
documentation supporting a license application for MOX fuel use be obtained before fabrication of the MOX fuel begins. GE recommends reestablishing the limited-scale MOX fuel use licensing strategy employed in the 1970s and, through operational success and further research and development, establish the technology base and licensing approach needed to obtain NRC approval for a $100 \%$ MOX core. Westinghouse proposes that the utility/consortia apply to NRC for a manufacturer's license under $10 \mathrm{CFR} 52$, Appendix $\mathrm{M}$, and, through this license application, address all technical and licensing issues associated with MOX fuel fabrication, qualification, transportation, plant performance, and environmental impacts generically. Each licensing strategy has its own merits, and, because the success of the licensing strategies are highly dependent on the technical and organizational strengths of the competing utilities/consortia and the design bases/operating histories of the candidate reactor(s) bidding for the MOX fuel irradiation services, none of the strategies are clearly superior to the others. [ORNL recommendation: NRC input on the viability of the proposed licensing strategies should be obtained during the MOX fuel irradiation services procurement process.]

In considering the different approaches to obtaining NRC authorization for MOX fuel irradiation, it is important to note the following: When, in situations where MOX fuel cores are employed in place of standard $\mathrm{UO}_{2}$ cores, the reactor(s)' response to normal operating transients and design basis accidents results in increased safety margins, NRC will likely want the additional margins maintained until a new base of domestic operating experience demonstrates that the margins are not needed. Conversely, when the reactor(s)' response results in reduced safety margins, NRC will almost certainly require compensatory actions (i.e., plant modifications, procedure changes, etc.) to reestablish the margins that make up the existing plant licensing basis before granting approval for MOX fuel assembly installation. As such, almost any technical or administrative matter that evolves from the utility/consortia's, DOE's, or NRC's evaluations of MOX fuel use has the potential to become a significant licensing issue requiring resolution with NRC before any MOX fuel assemblies can be irradiated. Therefore, once the utility/consortia for providing the MOX fuel fabrication/irradiation services has been selected by DOE, clear, frequent, and open communications with NRC on the licensing strategy to be employed and the issues emerging from the technical and regulatory reviews will be the key to a timely commencement of the plutonium consumption track of the overall DOE materials disposition mission.

\section{BIBLIOGRAPHY}

"Agency Role in Weapons Plutonium Disposal Mission Undefined, But Broad," Inside NRC, February 3, 1997-Location: The McGraw-Hill Companies, Subscriber Relations Department, Energy \& Business Newsletters, 1221 Avenue of the Americas, New York, NY 10020.

"Briefing by DOE on Plutonium Disposition," January 27, 1997 (transcript and overheads)-Location: Ann Riley \& Associates, Ltd., 1250 I Street, N.W., Suite 300, Washington, D.C. 20005.

B. S. Cowell, G. L. Copeland, and D. L. Moses, Fissile Materials Disposition Program Fuel Qualification Requirements for Reactor-Based Plutonium Disposition, ORNL/TM-13405, Lockheed Martin Energy Research Corp., Oak Ridge National Laboratory, in press-Location: Oak Ridge National Laboratory, P.O. Box 2009, Oak Ridge, TN 37831-8065 (Attention: D. J. Spellman).

DOE Plutonium Study: Core Designs for Existing ABB-CE System 80 Reactors for the Disposition of Weapons-Grade Plutonium, Final Report by ABB-Combustion Engineering, Windsor, CT, October 25, 1996 (Predecisional-Not for Public Release).

Effects of Plutonium Utilization on the Performance of Light Water Reactors, WASH-1303, March 1974 Location: Oak Ridge National Laboratory, P.O. Box 2009, Oak Ridge, TN 37831-8065 (Attention: D. J. Spellman).

Final Generic Environmental Statement on the Use of Recycle Plutonium in Mixed Oxide Fuel in Light Water Cooled Reactors, NUREG-0002, U.S. Nuclear Regulatory Commission, August 1976Location: National Technical Information Services, 5285 Port Royal Road, Springfield, VA 22161.

"Jackson Intends to Increase NRC Financial Capabilities Without Intruding," Inside NRC, January 6, 1997-Location: The McGraw-Hill Companies, Subscriber Relations Department, Energy \& Business Newsletters, 1221 Avenue of the Americas, New York, NY 10020. 
"Legal and Licensing Issues Relating to the Burning of MOX Fuel in Licensed Nuclear Power Reactors," H. K. Shapar; Shaw, Pittman, Potts, and Trowbridge; International Uranium Fuel Seminar, September 29-October 2, 1996; St. Petersburg, FL-Location: Nuclear Energy Institute, 1776 I Street, Suite 400, Washington, D.C. 20006-3708.

Letter from F. M. Killar, Nuclear Energy Institute, to participants in February 21, 1997, NEI/NRC technical exchange on use of MOX fuel in light water reactors, March 4, 1997-Location: Nuclear Energy Institute, 1776 I Street, Suite 400, Washington, D.C. 20006-3708.

Letter from K. Goller, USAEC, to J. S. Abel, Commonwealth Edison (SER for Quad Cities for MOX fuel), June 7, 1974-Location: Oak Ridge National Laboratory, P.O. Box 2009, Oak Ridge, TN 37831-8065 (Attention: D. J. Spellman).

Letter from L. D. White, Rochester Gas \& Electric, to D. L. Ziemann, NRC (Response to staff questions on use of MOX fuel), February 28, 1980-Location: Oak Ridge National Laboratory, P.O. Box 2009, Oak Ridge, TN 37831-8065 (Attention: D. J. Spellman).

"McGaffigan Questions Wisdom of Spending on MOX While Russian Pu at Risk," Inside NRC, February 17, 1997-Location: The McGraw-Hill Companies, Subscriber Relations Department, Energy \& Business Newsletters, 1221 Avenue of the Americas, New York, NY 10020.

Memorandum from H. R. Denton, NRC, to the NRC Commissioners via W. J. Dircks (NRC Staff recommendation to approve storage of MOX fuel assemblies at Ginna), February 5, 1980-Location: Oak Ridge National Laboratory, P.O. Box 2009, Oak Ridge, TN 37831-8065 (Attention: D. J. Spellman).

Memorandum from J. C. Hoyle, NRC, to L. J. Callan, K. D. Cyr, and R. Scroggins, NRC [Staff Requirements-COMSECY-96-053-Oversight of the Department of Energy (DSI 2)], March 28, 1997-Location: Oak Ridge National Laboratory, P.O. Box 2009, Oak Ridge, TN 37831-8065 (Attention: D. J. Spellman).

Minutes of ABB-Combustion Engineering Project Review Meeting, December 16, 1996, Oak Ridge, Tennessee, ORNL/MD/LTR-71, Lockheed Martin Energy Research Corp., Oak Ridge National Laboratory, February 21, 1997 (Predecisional-Not for Public Release).

Minutes of General Electric Vendor Review Meeting, November 7, 1996, Oak Ridge, Tennessee, ORNL/MD/LTR-57, Lockheed Martin Energy Research Corp., Oak Ridge National Laboratory, November 25, 1996 (Predecisional-Not for Public Release).

Minutes of Westinghouse Electric Company Project Review Meeting, November 18, 1996, Oak Ridge, Tennessee, ORNL/MD/LTR-58, Lockheed Martin Energy Research Corp., Oak Ridge National Laboratory, December 6, 1996 (Predecisional-Not for Public Release).

Optimization and Implementation Study of Plutonium Disposition Using Existing GE Boiling Reactors, NEDO-32638, September 30, 1996 (Predecisional-Not for Public Release).

Plutonium Disposition Study-Implementation of Weapons Grade MOX Fuel in Existing Pressurized Water Reactors for the Department of Energy, Oakland, California, DOE/SF/19683-7, U.S. Department of Energy, August 30, 1996 (Predecisional-Not for Public Release).

"Practical Aspects of Burning Weapons-Useable Plutonium in U.S. Commercial Reactors," R. Von Namen, Duke Power Company, International Uranium Fuel Seminar, September 29-October 2, 1996; St. Petersburg, FL-Location: Nuclear Energy Institute, 1776 I Street, Suite 400, Washington, D.C. 20006-3708.

Storage and Disposition of Weapons-Useable Fissile Materials Final Programmatic Environmental Impact Statement, DOE/EIS-0229, U.S. Department of Energy, December 1996-Location: National Technical Information Services, 5285 Port Royal Road, Springfield, VA 22161. 
Page Intentionally Blank 
ORNL/TM-13421

Dist. Category UC-523

\section{INTERNAL DISTRIBUTION}

1. S. L. Byerly

2. E. C. Fox

3. S. R. Greene

4. T. W. Horning

5. G. T. Mays

6. G. E. Michaels

7. D. L. Moses

8. D. G. O'Connor
9. P. L. Rittenhouse

10. C. C. Southmayd

11. D. J. Spellman

12-16. D. L. Williams, Jr.

17. Central Research Library

18-19. ORNL Laboratory Records (OSTI)

20. ORNL Laboratory Records-RC

\section{EXTERNAL DISTRIBUTION}

21. D. J. Nulton, U.S. Department of Energy, MD-4, Forrestal Building, Room 6G-050, 1000 Independence Avenue SW, Washington, DC 20585.

22-26. P. T. Rhoads, U.S. Department of Energy, MD-3, Forrestal Building, Room 6G-050, 1000 Independence Avenue SW, Washington, DC 20585.

27. J. J. Buksa, Los Alamos National Laboratory, P.O. Box 1663, MS-F628, Los Alamos, NM 87545.

28. T. Barr, U.S. Department of Energy, EPG, Argonne National Laboratory, 9800 South Cass Avenue, Argonne, IL 60439.

\section{WWW DISTRIBUTION}

The FMDP Web site, with a list of other relevant topical reports, is located at the following URL:

http://www.ornl.gov/etd/FMDP/fmdpproc.htm 